OPEN ACCESS

Edited by:

Chong Sun,

China University of Petroleum, China

Reviewed by:

Jiankuan $L i$

University of Alberta, Canada Yong Xiang,

China University of Petroleum, China

*Correspondence: Zhu Wang

wangzhu1303@126.com

Specialty section: This article was submitted to Environmental Degradation of

Materials,

a section of the journal

Frontiers in Materials

Received: 22 June 2021

Accepted: 28 July 2021

Published: 07 September 2021

Citation:

Feng Z, Fan X, Wang Z, Yu Y, Chen L, Du $Y$ and Dong L (2021) Corrosion

Behavior and Passive Film

Composition of Alloy 825 in High

Temperature and High $\mathrm{H}_{2} \mathrm{~S}-\mathrm{CO}_{2}$

Containing Environment.

Front. Mater. 8:728898.

doi: 10.3389/fmats.2021.728898

\section{Corrosion Behavior and Passive Film Composition of Alloy 825 in High Temperature and High $\mathrm{H}_{2} \mathrm{~S}-\mathrm{CO}_{2}$ Containing Environment}

\author{
Zhe Feng ${ }^{1}$, Xuehua Fan ${ }^{2}$, Zhu Wang ${ }^{1 *}$, Yong Yu ${ }^{2}$, Lijuan Chen $^{2}$, Yanxia Du ${ }^{1}$ and Lei Dong ${ }^{2}$ \\ ${ }^{1}$ Institute for Advanced Materials and Technology, University of Science and Technology Beijing, Beijing, China, ${ }^{2}$ China Petroleum \\ Engineering and Construction Co., Ltd. Beijing Company, Beijing, China
}

The effect of high temperature on corrosion behavior and passive film composition of Ni-based alloy 825 in $\mathrm{H}_{2} \mathrm{~S}$-containing environment was investigated by Confocal Laser Microscope (CLM), Scanning Electron Microscope (SEM), Energy Dispersive Spectrometer (EDS), and X-ray Photoelectron Spectroscopy (XPS). The experiment was carried out at 150 and $230^{\circ} \mathrm{C}$ in $\mathrm{NaCl}$ solution. The partial pressure of $\mathrm{H}_{2} \mathrm{~S}$ was set to $1.2 \mathrm{MPa}$ and $\mathrm{CO}_{2}$ was set to $3.2 \mathrm{MPa}$. The results showed that Ni-based alloy 825 presented good general corrosion resistance. Pitting corrosion was likely to occur at $230^{\circ} \mathrm{C}$ because of $\mathrm{Cr}$ depleted in the passive film. NiS appeared at high temperature and is damaging to protectiveness of passive film.

Keywords: nickel based alloy, hydrogen sulfide, pitting, passive film, high temperature

\section{INTRODUCTION}

With the increase in energy demand and development in oil field exploitation methods, ultra-deep oil and gas fields have gradually increased. During cooperation with colleagues in field, we found the environment in working condition is more severe than expected. As depth increases, downhole equipment is facing temperatures above $100^{\circ} \mathrm{C}$. Because of the high $\mathrm{H}_{2} \mathrm{~S}$, high $\mathrm{Cl}^{-}$, and high $\mathrm{CO}_{2}$ that exist in the downhole environment, materials usually used in production suffer from decreasing corrosion resistance. Carbon steel will face high corrosion risk in the harsh corrosive environment (Javidi and Bekhrad, 2018). Nickel-based alloys with better corrosion resistance are used in production equipment. There was plenty of research about the corrosion behavior at temperature lower than $200^{\circ} \mathrm{C} . \mathrm{H}_{2} \mathrm{~S}$ partial pressure was stabilized at several $\mathrm{KPa}$. This didn't match to the high temperature and high $\mathrm{H}_{2} \mathrm{~S}$ partial pressure in production. There are few reports on the passive film composition of alloy 825 under extreme environments. The relation between passive film composition and corrosion resistance still needs to be studied. Incoloy 825 is the most widely used Ni-based alloy in engineering. Its high content of $\mathrm{Cr}$ and $\mathrm{Ni}$ makes for great passivation performance and good corrosion resistance. Early research had discovered the passivation ability of $\mathrm{Cr}$ (Kirchheim et al., 1989) and it became a common element in various stainless steels. Mo is a typical additive to improve the stability of passive film and prevent occurrence of localized corrosion (Laszczyńska et al., 2017; Hendersona et al., 2018).

However, Ni-based alloys cannot be corrosion-free in extreme environments. There were many researchers in related fields. Elshawesh et al. (2015) had reported a failure case of a 825 joint in $\mathrm{CO}_{2} / \mathrm{H}_{2} \mathrm{~S}$ environment at $60^{\circ} \mathrm{C}$ which was caused by pitting corrosion in long-term service. Banaś et al. (2007) presented $\mathrm{S}^{2-}$ ion could hinder the formation of oxide film and changed the corrosion mechanism of alloys. Ding et al. (2014) believed $\mathrm{H}_{2} \mathrm{~S}$ accelerate the anodic and cathodic reactions of stainless steel. $\mathrm{H}_{2} \mathrm{~S}$ could reduce the corrosion resistance of materials by changing the electrochemical properties of passive 
TABLE 1 | The chemical composition of 825 (wt\%).

\begin{tabular}{|c|c|c|c|c|c|c|c|c|c|c|c|}
\hline Alloy & C & $\mathrm{Cr}$ & Mn & $\mathrm{Si}$ & $\mathrm{Cu}$ & Mo & $\mathbf{S}$ & Al & $\mathrm{Ti}$ & $\mathrm{Fe}$ & $\mathrm{Ni}$ \\
\hline 825 & 0.01 & 21.3 & 0.45 & 0.18 & 2.24 & 3.08 & 0.003 & 0.21 & 0.75 & 30 & bal \\
\hline
\end{tabular}

film. Alexander et al. (2018) compared the difference of corrosion mechanism between duplex stainless steel and nickel-based alloy in $\mathrm{H}_{2} \mathrm{~S}$ environment. Both materials showed the susceptibility of selective corrosion. Dong et al. (2011) revealed the increase of austenite phase could increase the corrosion resistance of crevice corrosion. Cheng et al. (2000) proved the presence of nickel sulfide and $\mathrm{H}_{2} \mathrm{~S}$ accelerated the corrosion rate of Alloy 825 by using an electrochemistry method. Temperature can influence the corrosion resistance of materials. Zhao et al. (2011) tested Ni-based alloy using a solution containing $\mathrm{H}_{2} \mathrm{~S} / \mathrm{CO}_{2}$ and found the increase in temperature resulted in a higher corrosion rate while presence of elemental sulfur led to localized corrosion. Elizabeth et al. (2014) used optical measurement to observe corrosion behavior 825 in $3 \mathrm{M} \mathrm{NaCl}$ with $\mathrm{CO}_{2}$ at $250^{\circ} \mathrm{C}$. However, the downhole environment is much more severe. The $\mathrm{Cl}^{-}$concentration is nearly saturated under severe working conditions and the $\mathrm{H}_{2} \mathrm{~S}$ and $\mathrm{CO}_{2}$ could reach $\mathrm{MPa}$ level. Further research on Ni-based alloy corrosion behavior under severe conditions is still needed.

In this paper, the corrosion resistance of the passive film of $\mathrm{Ni}$ based alloys has been further studied by using Confocal Laser Microscope (CLM), Scanning Electron Microscope (SEM), Energy Dispersive Spectrometer (EDS), and X-ray photoelectron spectroscopy (XPS). The pitting corrosion behavior of Alloy 825 by changing the temperature in a high $\mathrm{Cl}^{-}$high $\mathrm{H}_{2} \mathrm{~S} / \mathrm{CO}_{2}$ environment is discussed.

\section{MATERIALS AND METHODS}

\section{Materials and Solutions}

All test specimens were cut from an $825 \mathrm{Ni}$-based Alloy plate. The chemical composition of 825 is listed in Table $\mathbf{1}$.
The corrosion test specimens were cut to $40 \mathrm{~mm} \times 20 \mathrm{~mm}$ $\times 3 \mathrm{~mm}$. The specimens for surface characterization were cut to $10 \mathrm{~mm} \times 10 \mathrm{~mm} \times 3 \mathrm{~mm}$ in size. All samples were cleaned with acetone, alcohol, and deionized water after machining. Corrosion test specimens were polished to 600\# and surface characterization specimens were successively polished to 2000\# to make it suitable for SEM and XPS test. Specimens were cleaned by deionized water and alcohol, then dried by cool air, and then weighed.

For a more precise simulation of working condition, $350 \mathrm{~g} \mathrm{~L}^{-1}$ $\mathrm{NaCl}$ was applied in an immersion test. The test solution containing approximately $350 \mathrm{~g} \mathrm{~L}^{-1} \mathrm{NaCl}$ were purged with $\mathrm{N}_{2}$ for $2 \mathrm{~h}$. Before the test, solution was saturated with $\mathrm{CO}_{2}$ and then $\mathrm{H}_{2} \mathrm{~S}$ was introduced and stabilized at $1.2 \mathrm{MPa}$. The partial pressure of $\mathrm{CO}_{2}$ is controlled to $3.2 \mathrm{MPa}$ which is similar to working condition. As the gas pressure is fully stabilized, the autoclaves were heated to 150 and $230^{\circ} \mathrm{C}$, respectively. The test duration was set to be $720 \mathrm{~h}$. The total pressure of two conditions is about $5 \mathrm{MPa}$ after heating.

\section{Weight Loss}

After experiment, specimens were taken out of the autoclave. Deionized water and acetone were used to rinse. The specimens were blow-dried by cool wind. The corrosion product was removed by $15 \% \mathrm{HCl}$ and then weighed. The corrosion rate was calculated by the following equation:

$$
C R=\frac{87600 W}{A \times t \times \mathrm{D}}
$$

where CR is the corrosion rate $(\mathrm{mm} / \mathrm{a}), W$ is for total weight loss (g), $A$ is for sample surface area $\left(\mathrm{cm}^{3}\right), t$ is for experiment time (s), $D$ is for density which is $8.14 \mathrm{~g} / \mathrm{cm}^{3}$ for Alloy 825 .
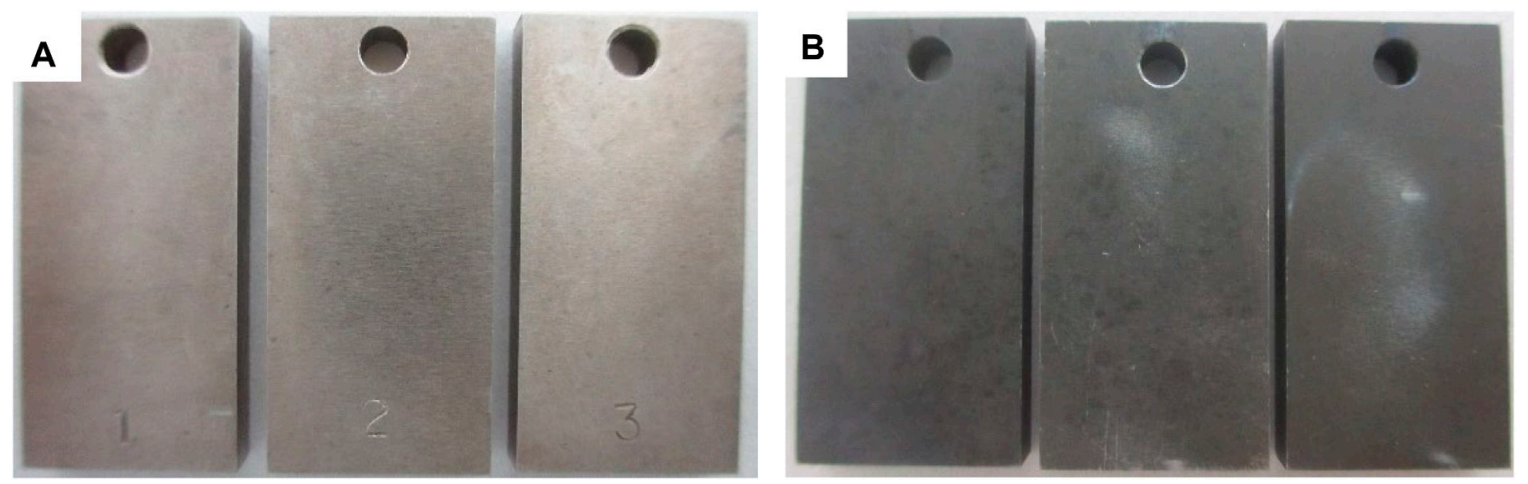

FIGURE 1 | Macro-morphology of 825 sample after the immersion tests at different temperatures: (A) no obvious corrosion product at $150^{\circ} \mathrm{C}$, (B) black corrosion product at $230^{\circ} \mathrm{C}$ 

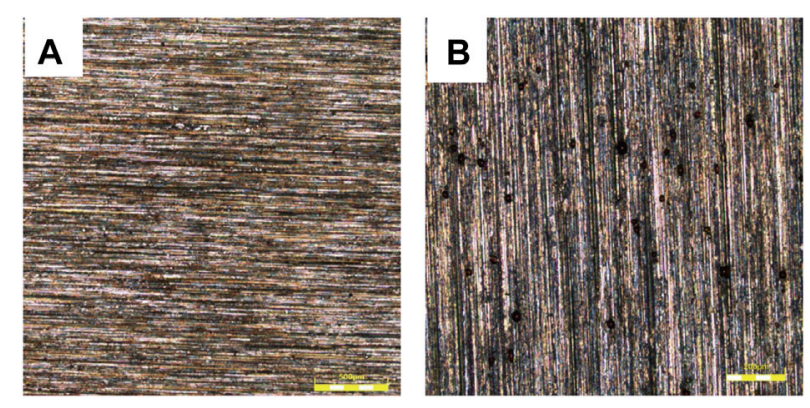

FIGURE 2 | Micro-morphology of 825 sample after the immersion tests at different temperatures without remove corrosion products: (A) no pit observed at $150^{\circ} \mathrm{C}$. (B) black pits founded at $230^{\circ} \mathrm{C}$.

\section{Surface Morphology}

CLM and SEM were used to observe the corrosion product on the specimen. After the immersion test, the specimens were rinsed with deionized water and dried by cool air. The surface of the specimens was analyzed using CLM to obtain the dimensional information of pits. A Quanta250 environmental SEM equipped with an EDS was used to analyzed the surface morphology and corrosion products. The depth of corrosion pits was acquired and pitting corrosion rate was calculated by the following equation:

$$
C R_{p}=\frac{8760 D}{t}
$$

where $C_{P}$ is the pitting corrosion rate $(\mathrm{mm} / \mathrm{a}), D$ is for depth of the deepest pits $(\mathrm{mm})$, and $t$ is for experiment time (h).

\section{Surface Characterization}

The composition of the passive films formed at various temperatures was analyzed by XPS with a PHI5000 VersaProbe III [monochromatic Al Ka (hv = 1,486.6 eV), analysis angle $45^{\circ}$. The shift change was adjusted by $\mathrm{C} 1 \mathrm{~s}$ at $284.8 \mathrm{eV}$. XPSPEAK 41 was used to analyzed the XPS result.

\section{RESULT}

\section{Corrosion Rate}

We used Eq. 1 to calculate the general corrosion rate. The corrosion rate is $0.0007 \pm 0.0001 \mathrm{~mm} / \mathrm{a}$ for $150^{\circ} \mathrm{C}$ and $0.0010 \pm 0.0001 \mathrm{~mm} / \mathrm{a}$ for $230^{\circ} \mathrm{C}$. The Alloy suffered from higher general corrosion rate at $230^{\circ} \mathrm{C}$ than $150^{\circ} \mathrm{C}$. However, it should be pointed out that corrosion rates were extremely low, indicating Alloy 825 showed good general corrosion resistance under the testing conditions.

\section{Surface Morphology}

Figure 1 shows the morphology of Alloy 825 samples after the immersion tests at different temperatures. It was observed that samples lost metallic luster after test.

Figure 2 shows the micro-morphology of the 825 sample after the immersion tests at different temperatures. There is no obvious pit on the surface of the sample tested at $150^{\circ} \mathrm{C}$. A large number of pits were found at $230^{\circ} \mathrm{C}$. Several researches (Banaś et al., 2007; Tomio et al., 2015) indicated that in $\mathrm{H}_{2} \mathrm{~S}$-containing environments the Ni-Cr-Mo alloy would form oxides of $\mathrm{Cr}$ and Mo and black sulfides such as FeS, NiS, and $\mathrm{MoS}_{2}$ on the surface. The composition of passive film is different from that formed in $\mathrm{H}_{2} \mathrm{~S}$-free environment (Wang et al., 2017; Wang et al., 2018; Wang et al., 2020).

Figure 3 shows micro-morphology of the 825 sample after removal of the corrosion products. The corrosion product was removed with $15 \% \mathrm{HCl}$. The samples tested at $150^{\circ} \mathrm{C}$ showed no pit on the surface, and no height difference caused by corrosion was observed on the entire surface. A large number of pits could be clearly found on the surface of the specimen and were evenly distributed on the surface at $230^{\circ} \mathrm{C}$. The depth of pits ranged from 7 to $10 \mu \mathrm{m}$. The pitting corrosion rate was $0.12 \mathrm{~mm} / \mathrm{a}$ according to Eq. 2. The rising temperature greatly increased localized corrosion susceptibility of Alloy 825 in a sulfur-containing environment.

Figure 4 shows the SEM images of Alloy 825 sample after the immersion tests. A layer of film could be observed on the surface of the sample tested in $3.2 \mathrm{MPa} \mathrm{CO}_{2}, 1.2 \mathrm{MPa} \mathrm{H}_{2} \mathrm{~S}$ at $150^{\circ} \mathrm{C}$. The film was intact and had no obvious corrosion product accumulation. The
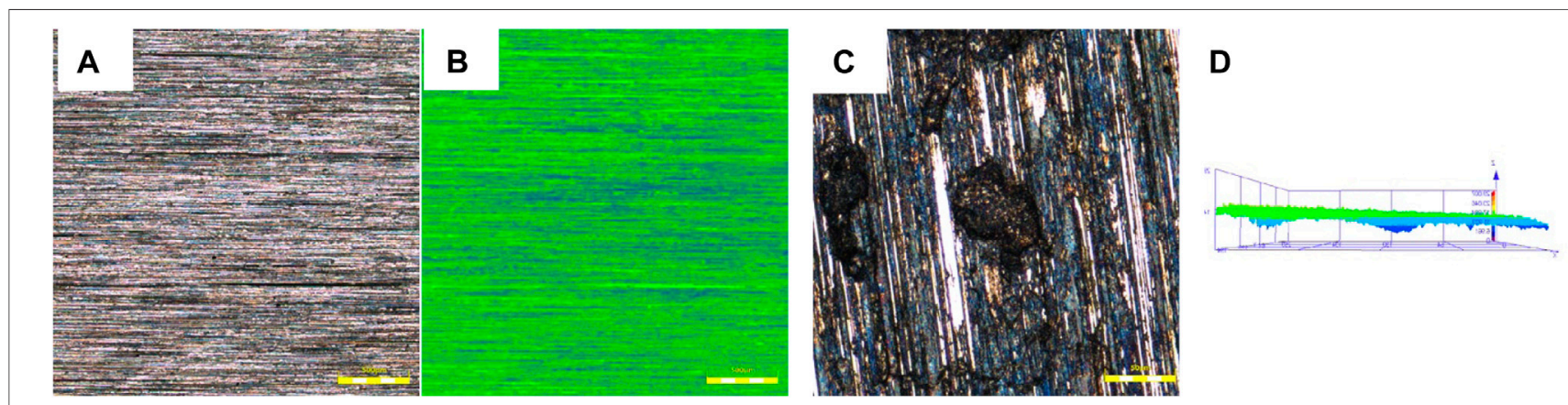

FIGURE 3 | Micro-morphology of 825 sample after removal of the corrosion products at different temperatures: (A, B) no pit founded at $150^{\circ} \mathrm{C}$. (C, D) black pits founded at $230^{\circ} \mathrm{C}$ and scanned by CLM. 

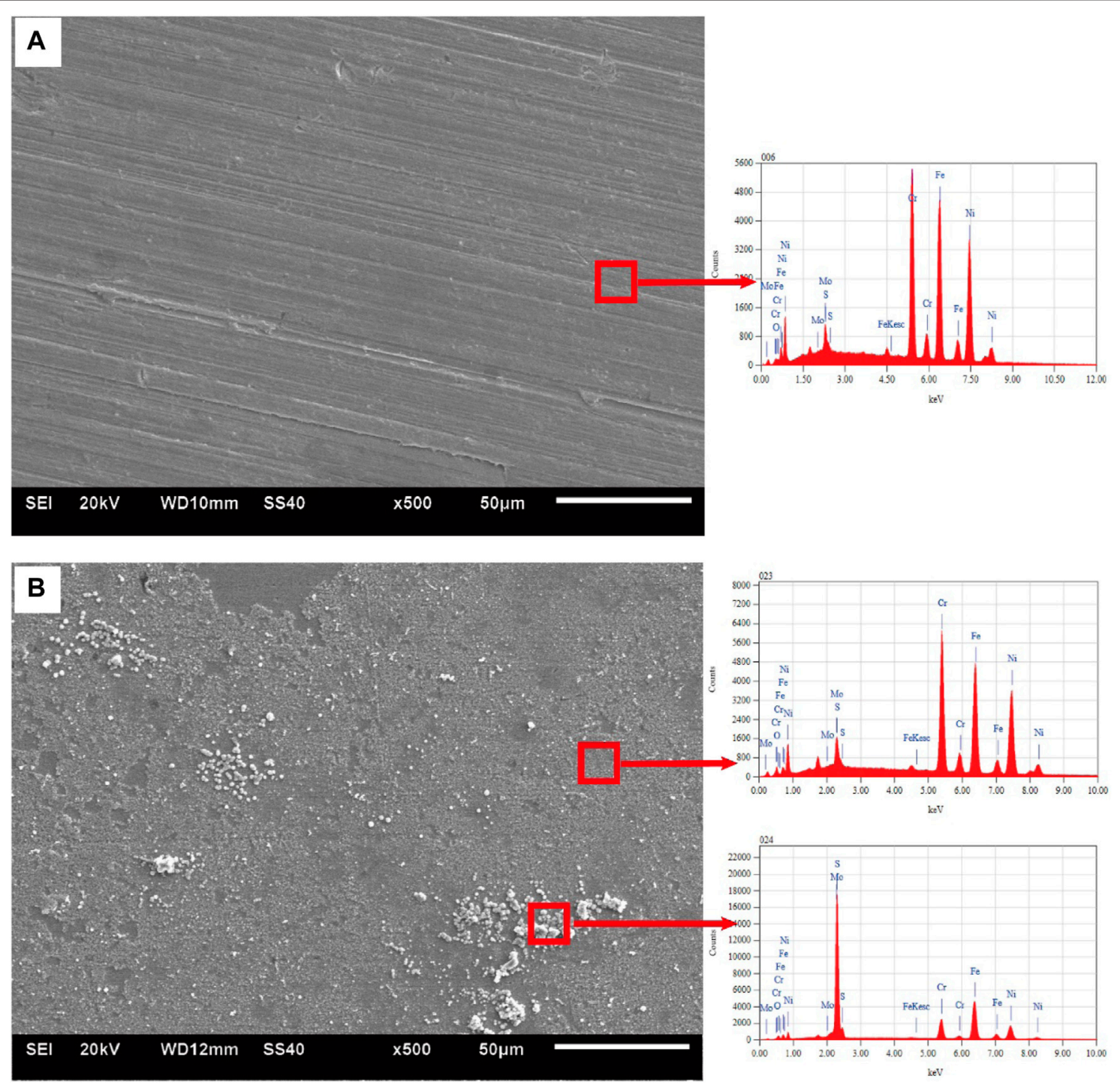

FIGURE 4 | SEM and EDS result of Alloy 825: (A) no obvious corrosion products at $150^{\circ} \mathrm{C}$ (B) particle corrosion products observed at $230^{\circ} \mathrm{C}$.

material showed good corrosion resistance in this environment. The particles corrosion product appeared at $230^{\circ} \mathrm{C}$, indicating the corrosion tendency at $230^{\circ} \mathrm{C}$ is higher than that at $150^{\circ} \mathrm{C}$. Scratches still could be seen over the surface, which suggested the material had strong resistance to general corrosion. This is consistent with the results in Corrosion Rate. EDS was used to analyze the surface corrosion product film. The analysis found corrosion product film contains a small amount of sulfur element and the sulfur content in the particle corrosion product is much greater than corrosion product film.

\section{XPS Result}

For corrosion product deposited on the corrosion product film and the corrosion product film, XPS is used for composition analysis. All samples were sputtered for $30 \mathrm{~s}$ to remove the outermost product film. The sampling depth of XPS is $0.5-2 \mathrm{~nm}$ for metals and about $1-3 \mathrm{~nm}$ for inorganic products.
Figure 5 shows the result of XPS results at $150^{\circ} \mathrm{C}$. It mainly contained $\mathrm{Cr}, \mathrm{Fe}, \mathrm{Ni}, \mathrm{Mo}$, and $\mathrm{O}$ and $\mathrm{S}$. The $\mathrm{Cr}$ shows obvious split peaks. The peaks were corresponding to $\mathrm{Cr}_{2} \mathrm{O}_{3}(576.8 \mathrm{eV})$ and $\mathrm{CrO}_{3}$ $(578.5 \mathrm{eV})$. Cr oxides were still formed in high-temperature $\mathrm{H}_{2} \mathrm{~S}$-containing environment which was the main reason for Alloy 825 to maintain good corrosion performance under severe conditions. Fe spectrum were mainly composed of $\mathrm{Fe}_{2} \mathrm{O}_{3}(710.9 \mathrm{eV})$ and $\mathrm{FeS}(713.8 \mathrm{eV})$. It can be determined the corrosion products are $\mathrm{Fe}^{2+} / \mathrm{Fe}^{3+}$ oxides and sulfides in the passive film. The content of Mo in the passive film is the least of the four elements. Its spectrum was split into three peaks of $\mathrm{Mo}, \mathrm{MoS}_{2}$, and $\mathrm{MoO}_{3}$. The Ni spectrum mainly consisted of $\mathrm{Ni}(\mathrm{OH})_{2}(861.2 \mathrm{eV})$ and satellites. $\mathrm{O}$ spectrum was divided into $\mathrm{O}^{2-}(530.2 \mathrm{eV})$ and $\mathrm{OH}^{-}(531.6 \mathrm{eV})$. The peak of $\mathrm{S}$ was mainly $\mathrm{S}^{2-}(530.2 \mathrm{eV})$.

Figure 6 shows the surface XPS results at $230^{\circ} \mathrm{C}, 1.2 \mathrm{MPa} \mathrm{H}_{2} \mathrm{~S}$, 3.2 $\mathrm{MPaCO}_{2}$. The $\mathrm{Cr}$ and Fe spectra could be separated to similar 

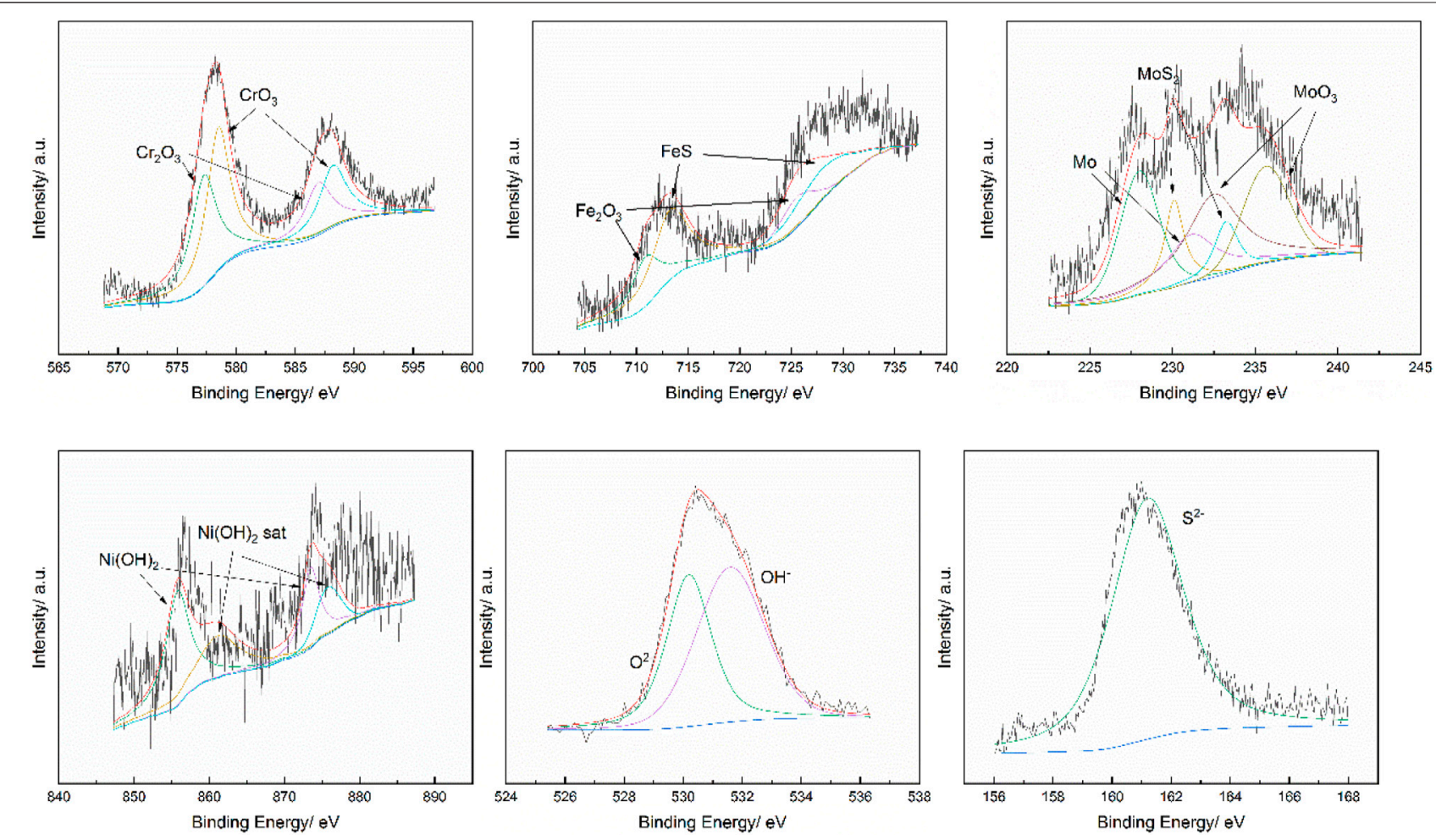

FIGURE 5 | XPS analysis results for Alloy 825 at $150^{\circ} \mathrm{C}, 1.2 \mathrm{MPa} \mathrm{H}_{2} \mathrm{~S} 3.2 \mathrm{MPa} \mathrm{CO}_{2}$.
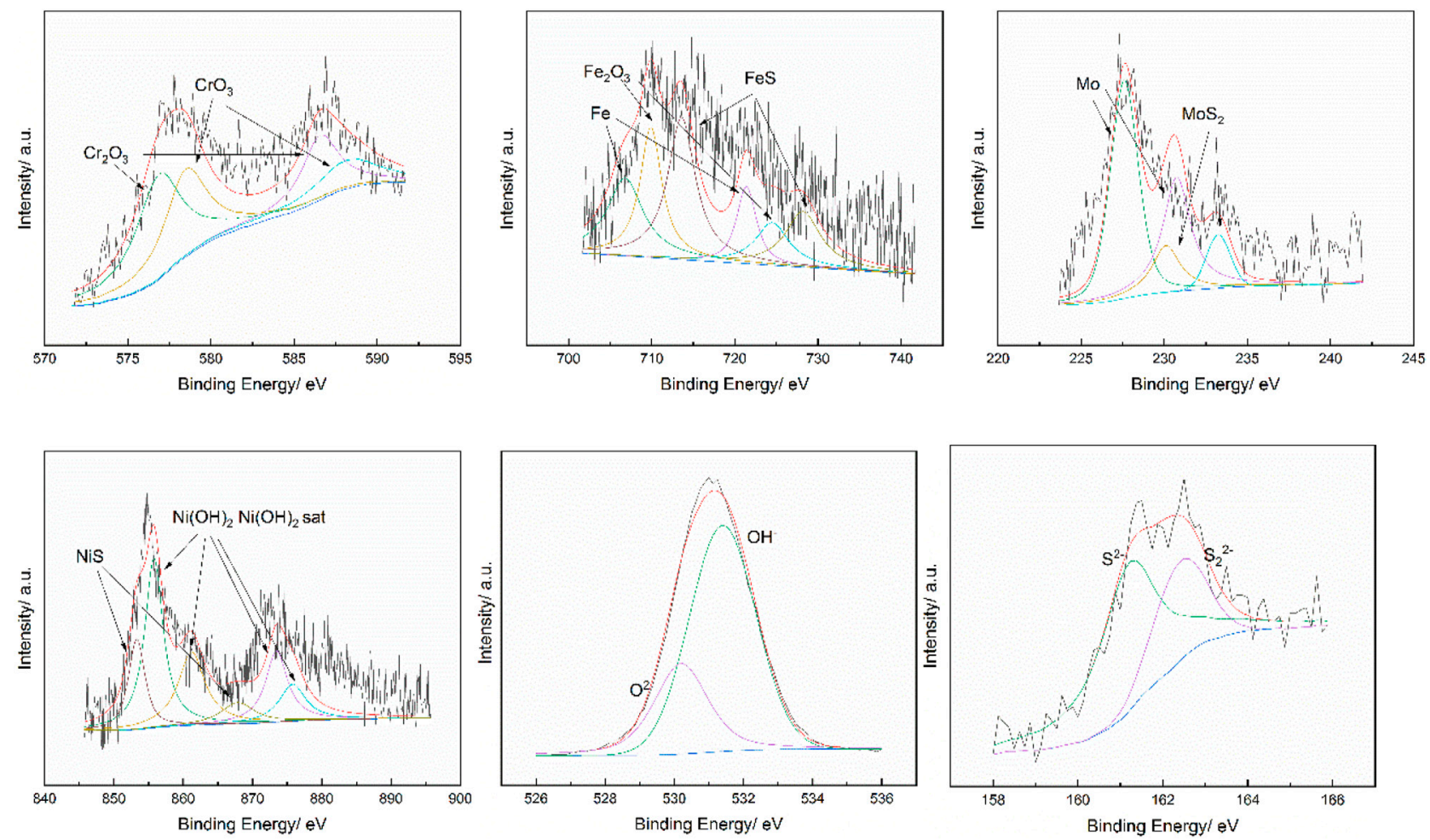

FIGURE 6 | XPS analysis results for Alloy 825 at $230^{\circ} \mathrm{C}, 1.2 \mathrm{MPa} \mathrm{H}_{2} \mathrm{~S} 3.2 \mathrm{MPa} \mathrm{CO}_{2}$. 
peak as $150^{\circ} \mathrm{C}$. There were Mo and $\mathrm{MoS}_{2}$ in the Mo spectrum. However, $\mathrm{MoO}_{3}$ disappeared at $230^{\circ} \mathrm{C}$.

$\mathrm{Ni}$ formed $\mathrm{NiS}$ and $\mathrm{Ni}(\mathrm{OH})_{2}$ at $230^{\circ} \mathrm{C}$. The appearance of sulfides in the passive film lead to a decrease in general corrosion resistance and induced pitting corrosion. The $\mathrm{O}$ spectrum was composed by $\mathrm{O}^{2-}$ and $\mathrm{OH}^{-}$which is the same as the result at $150^{\circ} \mathrm{C}$. The $\mathrm{S}$ spectrum could be separated to different peaks of $\mathrm{S}^{2-}$ and $\mathrm{S}_{2}{ }^{2-}$.

Figure 7 shows the relative proportions of the elements in the passive film under the two conditions. As the temperature increased, the content of $\mathrm{Cr}$ in the passive film reduced. At $150^{\circ} \mathrm{C}$, the relative proportion of $\mathrm{Cr}$ was above $60 \%$, which reduced to $20 \%$ after the temperature was increased to $230^{\circ} \mathrm{C}$. At the same time, the relative proportions of $\mathrm{Fe}$ and $\mathrm{Ni}$ increased. At $150^{\circ} \mathrm{C}$, the relative ratios of $\mathrm{Fe}$ and $\mathrm{Ni}$ in passive film were lower than that of $\mathrm{Cr}$ which was less than $15 \%$. However, when the temperature raised to $230^{\circ} \mathrm{C}$, the relative ratio was increased to about $30 \%$ for $\mathrm{Fe}$ and $40 \%$ for Ni. Mo kept about $10 \%$ in both conditions.

\section{DISCUSSION}

The increase in temperature influenced the corrosion behavior of nickel-based alloys in $\mathrm{H}_{2} \mathrm{~S}$-containing environments. It increased the corrosion rate and risk of pitting corrosion by affecting the composition of the passive film. From $150^{\circ} \mathrm{C}$ to $230^{\circ} \mathrm{C}$, changes occurred in the composition of the surface passive film of nickelbased Alloy 825. Under sulfur-containing conditions, S appeared in the passive film and sulfide had detrimental effect to isolated corrosive media.

At $150^{\circ} \mathrm{C}$, the content of $\mathrm{Cr}$ in the passive film was higher than that of Alloy 825 which showing enrichment in passive film. When temperature increased, the $\mathrm{Cr}$ in the passive film greatly reduced. This is consistent with other studies at lower temperatures which pointed out an increasing loss of $\mathrm{Cr}_{2} \mathrm{O}_{3}$ as temperature increases (Zhang and Shoesmith, 2013).

The oxides and sulfides of Fe were formed in both conditions. The content of $\mathrm{Fe}$ in the passive film increases with temperature. Low corrosion resistance of $\mathrm{Fe} / \mathrm{FeS}$ results in an increase in the dissolution rate at $230^{\circ} \mathrm{C}$.

At lower temperatures, $\mathrm{Ni}$ only formed the $\mathrm{Ni}(\mathrm{OH})_{2}$, while $\mathrm{NiS}$ was produced at high temperatures. Monnot (Monnot et al., 2017) found that appearance of sulfide will not only reduce the density of the film but also cause changes in the electrochemical property of passive film. The original ionselective oxide film converted to the sulfide film which was lacking in ion-selective. This promoted the permeation of corrosive ions such as $\mathrm{Cl}^{-}, \mathrm{S}^{2-}$, and $\mathrm{CO}_{3}{ }^{2}$ to the base metal, increasing the pitting susceptibility. Therefore, pitting corrosion occurred in 825 at $230^{\circ} \mathrm{C}$.

$\mathrm{Ni}(\mathrm{OH})_{2}$ has good corrosion resistance. At the same time, the relative content of $\mathrm{Ni}$ in the passive film was significantly increased, which is close to the proportion of $\mathrm{Ni}$ in Alloy 825. Because of the formation of sulfides, the composition of the passive film changes and the corrosion resistance is reduced. The cathodic reaction of $\mathrm{H}_{2} \mathrm{~S}$ corrosion is a series of depolarization

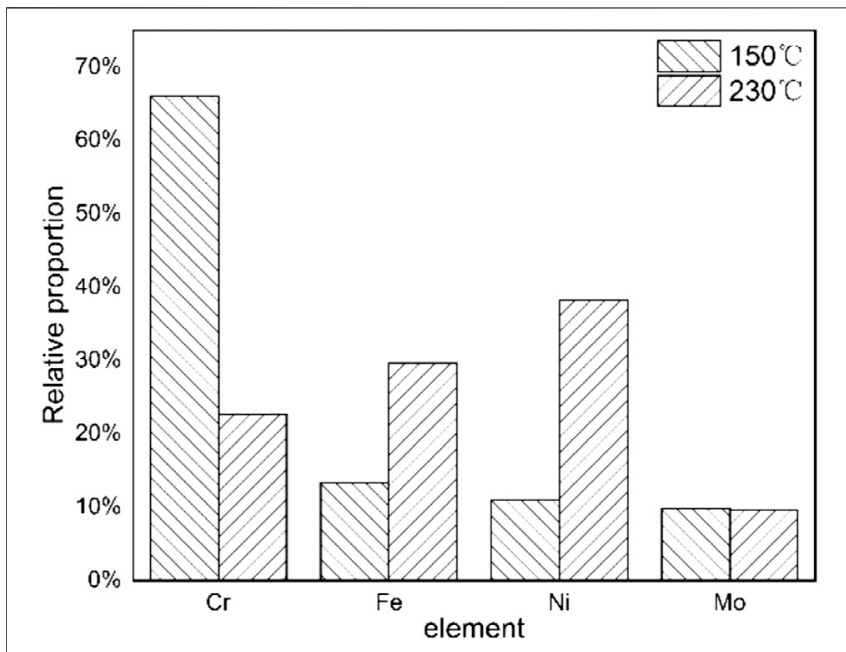

FIGURE 7 | The comparison of relative proportions of the elements in passive film of Alloy 825 under two conditions.

processes of $\mathrm{H}_{2} \mathrm{~S}, \mathrm{HS}^{-}$, and $\mathrm{H}^{+}$. It lowers the $\mathrm{pH}$ of the environment as in the following:

$$
\begin{gathered}
\mathrm{H}_{2} \mathrm{~S}+\mathrm{e}^{-} \rightarrow \mathrm{H}+\mathrm{HS}^{-} \\
\mathrm{HS}^{-}+\mathrm{e}^{-} \rightarrow \mathrm{H}+\mathrm{S}^{2-}
\end{gathered}
$$

The dissolution process of $\mathrm{Ni}$ at lower temperature is as following (Cheng et al., 2000):

$$
\begin{aligned}
& \mathrm{Ni}+\mathrm{H}_{2} \mathrm{~S}+\mathrm{H}_{2} \mathrm{O} \rightarrow \mathrm{Ni}(\mathrm{HS})_{a d s}+\mathrm{H}_{3} \mathrm{O}^{+}+\mathrm{e}^{-} \\
& \mathrm{Ni}(\mathrm{HS})_{a d s} \rightarrow \mathrm{NiHS}^{+}+\mathrm{e}^{-} \\
& \mathrm{NiHS}^{+}+\mathrm{H}_{3} \mathrm{O}^{+} \Leftrightarrow \mathrm{Ni}^{2+}+\mathrm{H}_{2} \mathrm{~S}+\mathrm{H}_{2} \mathrm{O}
\end{aligned}
$$

The hydrolysis reactions of $\mathrm{Ni}^{2+}$ lead to a formation of $\mathrm{Ni}(\mathrm{OH})_{2}$ at $150^{\circ} \mathrm{C}$.

At $230^{\circ} \mathrm{C}$, Ni forms NiS in the sulfur-containing environment. NiS was a common corrosion product of nickel-based alloys after localized corrosion (Zhao et al., 2011). The NiS is formed as follows (Banaś et al., 2007; Sun et al., 2019; Li et al., 2021):

$$
\mathrm{Ni}+\mathrm{H}_{2} \mathrm{~S}(\mathrm{aq}) \rightarrow \mathrm{NiS}+\mathrm{H}_{2}
$$

$\mathrm{NiS}$ could not form a protective layer at low $\mathrm{pH}$ (Davoodi et al., 2011) which caused continuous corrosion. The presence of NiS may be one of the reasons for the decreased protection of passivation film at high temperature.

The content of Mo in the Alloy 825 is relatively low. But it plays a critical role in improving performance of the passive film. The sulfide and oxide of Mo have a good insulation of corrosion environment. Previous studies have shown that oxides of Mo have good corrosion resistance (Tomio et al., 2015; Henderson et al., 2019). Its protective performance comes from the ability to form passive film with cation selectivity. But when the temperature reaches $230^{\circ} \mathrm{C}$, the following reaction may happen (Li et al., 2020a):

$$
\mathrm{MoO}_{3}+2 \mathrm{HS}^{-} \rightarrow \mathrm{MoS}_{2}+2 \mathrm{OH}^{-}+\mathrm{H}_{2}
$$

The reaction (9) is nearly impossible at room temperature and atmospheric pressure (Natishan et al., 1999). But 

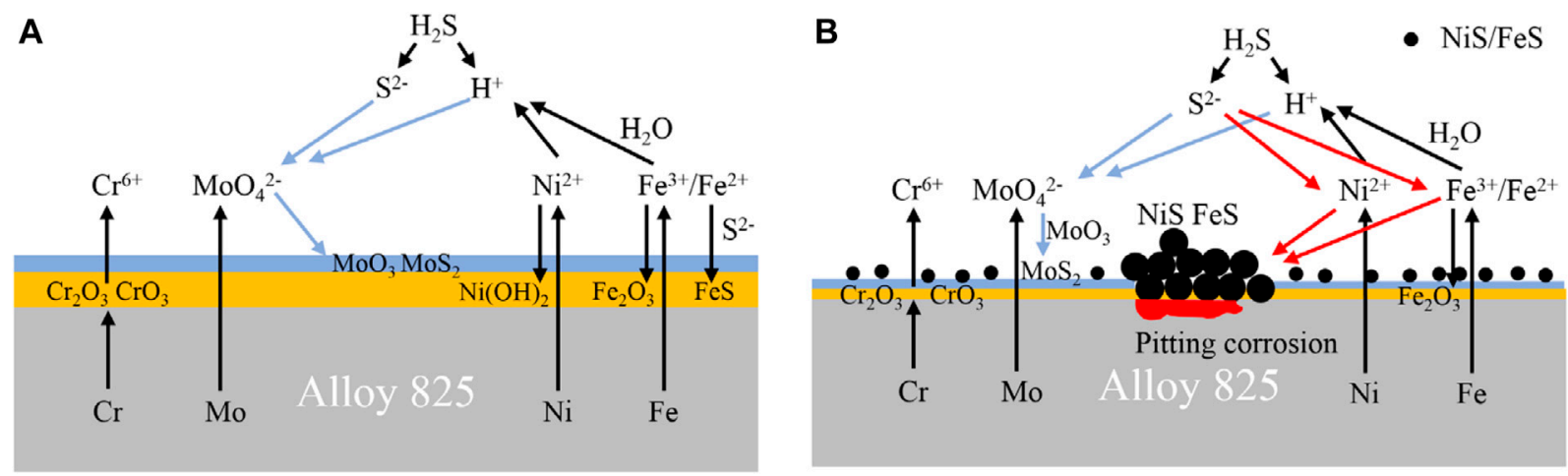

FIGURE 8 | The possible corrosion mechanism of Alloy 825 (A) $150^{\circ} \mathrm{C}$ (B) $230^{\circ} \mathrm{C}$.

$\mathrm{MoS}_{2}$ might formed in a sulfur-containing environment at $230^{\circ} \mathrm{C}$.

Figure 8 shows the possible mechanism of Alloy 825 in the experimental environment. The corrosion behavior of passive film at lower temperature has been studied extensively (Zhang and Shoesmith, 2013; Henderson et al., 2019; JianqiaoYang et al., 2020; Li et al., 2020b; Nimmervoll et al., 2021). As Figure 8A shows, Mo is enriched in the outer layer and $\mathrm{Ni} / \mathrm{Cr}$ in the metal border. This is the result of dissolution of passive film and the deposition of Mo oxide at low $\mathrm{pH}$. NiS does not form and amount of FeS is limited. Dissolution/formation of passive film is relatively slow. Therefore, a complete oxide passive film can be formed to keep good corrosion resistance. With the increase of temperature, the dissolution/formation process of the passive film is accelerated. Because of the higher diffusion ability of $\mathrm{Ni}$ than $\mathrm{Cr}$, it takes priority to combine with $\mathrm{S}^{2-}$ (Zhao et al., 2011), so NiS corrosion products are formed on the metal surface. $\mathrm{MoO}_{3}$ is converted to $\mathrm{MoS}_{2}$ with less corrosion resistance. The content of $\mathrm{Cr}$ is decreased in passive film. The surface was adhered by a loose layer of $\mathrm{NiS} / \mathrm{FeS}$ and Mo sulfide without precipitating a protective film on the metal. When corrosive solution reaches substrate, pitting corrosion happens.

In summary, the increase in temperature will cause the corrosion of Alloy 825 to accelerate in high $\mathrm{H}_{2} \mathrm{~S}$ environment. At $150^{\circ} \mathrm{C}, \mathrm{Cr}$ enriched passive film could still be formed on the surface of Alloy 825. There was only a small amount of FeS in the passive film, which had little effect on the corrosion resistance. The main composition of passive film was still $\mathrm{Cr}$ and $\mathrm{Ni}$ oxides. Oxides of Mo also provided great corrosion resistance. After the temperature rose to $230^{\circ} \mathrm{C}$, the relative proportion of $\mathrm{Cr}$ in the passive film reduced while the proportion of $\mathrm{Ni}$ and $\mathrm{Fe}$ increased. The appearance of sulfide reduced the protectiveness of the passive film. Therefore, the surface of the sample tested at $150^{\circ} \mathrm{C}$ has only a thin film of corrosion products. No partial corrosion products were attached to the film and no obvious localized corrosion phenomenon was on the surface. On the surface of the specimen at $230^{\circ} \mathrm{C}$, the performance of the passive film deteriorated and the corrosion rate increased. A thicker corrosion product layer appeared and partial corrosion product was attached to the surface. With defects in the passive film, pitting corrosion occurred.

\section{CONCLUSION}

In the present work, the corrosion behavior of Alloy 825 in high temperature with $\mathrm{CO}_{2} / \mathrm{H}_{2} \mathrm{~S}$ and composition of passive film were studied. Weight loss, CLM, SEM, EDS, and XPS were used to analyze the specimen.

The conclusion is listed as follows:

1) The general corrosion of Alloy 825 is relatively slow in environment with $3.2 \mathrm{MPa} \mathrm{CO}_{2}, 1.2 \mathrm{MPa} \mathrm{H}_{2} \mathrm{~S}$. Corrosion rate is $0.0007 \pm 0.0001 \mathrm{~mm} / \mathrm{a}$ for $150^{\circ} \mathrm{C}$ and $0.0010 \pm$ $0.0001 \mathrm{~mm} / \mathrm{a}$ for $230^{\circ} \mathrm{C}$.

2) No pitting corrosion occurred at $150^{\circ} \mathrm{C}$. When temperature raised to $230^{\circ} \mathrm{C}$, pitting corrosion was likely to occur on the Alloy 825 surface.

3) The passive film is mainly composed of $\mathrm{Cr}_{2} \mathrm{O}_{3}, \mathrm{CrO}_{3}, \mathrm{Fe}_{2} \mathrm{O}_{3}$, $\mathrm{FeS}, \mathrm{Ni}(\mathrm{OH})_{2}, \mathrm{Mo}, \mathrm{MoS}$ at $150^{\circ} \mathrm{C}$. At the higher temperature of $230^{\circ} \mathrm{C}$, NiS is present in the passive film.

4) $\mathrm{Cr}$ suffered from a rapid decline in proportion while $\mathrm{Fe}$ and $\mathrm{Ni}$ were more enriched in film when temperature raised from $150^{\circ} \mathrm{C}$ to $230^{\circ} \mathrm{C}$. NiS and $\mathrm{MoS}_{2}$ also occur in film which caused the losses of corrosion resistance. Therefore, Alloy 825 faced risk of pitting corrosion in high temperature.

\section{DATA AVAILABILITY STATEMENT}

The original contributions presented in the study are included in the article/supplementary material, further inquiries can be directed to the corresponding author. 


\section{AUTHOR CONTRIBUTIONS}

ZF finished the manuscript. He worked with XF and YY to analyze the results. ZW planned the scope of work. LC and LD conducted the immersion tests. YD revised the manuscript.

\section{REFERENCES}

Alexander, S., Moria, G., nigb, S. H., Weilc, M., Susanne, S., and Haubner, R. (2018). Comparison of the high-temperature chloride-induced corrosion between duplex steel and $\mathrm{Ni}$ based alloy in presence of H2S[J]. Corrosion Sci. 139, 76-82. doi:10.1016/j.corsci.2018.04.042

Banaś, J., Lelek-Borkowska, U., Mazurkiewicz, B., and Solarski, W. (2007). Effect of $\mathrm{CO} 2$ and $\mathrm{H} 2 \mathrm{~S}$ on the composition and stability of passive film on iron alloys in geothermal water[J]. Electrochimica Acta 52 (18), 5704-5714. doi:10.1016/ j.electacta.2007.01.086

Cheng, X., Ma, H., Chen, S., Chen, X., and Yao, Z. (2000). Corrosion of nickel in acid solutions with hydrogen sulphide[J]. Corrosion Sci. 42 (2), 299-311. doi:10.1016/S0010-938X(99)00092-X

Davoodi, A., Pakshir, M., Babaiee, M., and Ebrahimi, G. R. (2011). A comparative $\mathrm{H}_{2} \mathrm{~S}$ corrosion study of $304 \mathrm{~L}$ and $316 \mathrm{~L}$ stainless steels in acidic media[J]. Corrosion Sci. 53, 399-408. doi:10.1016/j.corsci.2010.09.050

Ding, J., Zhang, L., Lu, M., Wang, J., Wen, Z., and Hao, W. (2014). The electrochemical behaviour of $316 \mathrm{~L}$ austenitic stainless steel in $\mathrm{Cl}$-containing environment under different H2S partial pressures[J]. Appl. Surf. Sci. 289, 33-41. doi:10.1016/j.apsusc.2013.10.080

Dong, H., Jiang, Y., Shi, C., Zhao, L., and Jin, L. (2011). Influence of the microstructure and alloying element on the polarization behaviour within the crevice of UNS S32304 duplex stainless steel[J]. Corrosion Sci. 53 (11), 3796-3804. doi:10.1016/j.corsci.2011.07.030

Elizabeth, Q. C., Jin, H., Posusta, R. S., Sharma, D. K., Yan, C., Guraieb, P., et al. (2014). Optical measurement of uniform and localized corrosion of C1018, SS 410, and Inconel 825 alloys using white light interferometry[J]. Corrosion Sci. 87, 383-391. doi:10.1016/j.corsci.2014.06.046

Elshawesh, F., Elhoud, A., Zeglam, W., Abusowa, K., and Mesalem, A. (2015). Corrosion Fatigue of Incoloy 825 Flare Gas Line Bellows of Expansion Joints[J]. J. Fail. Anal. Prev. 15 (1), 7-14. doi:10.1007/s11668-014-9900-9

Henderson, J. D., Li, X., Shoesmith, D. W., Noël, J. J., and Kevin, O. (2019). Molybdenum surface enrichment and release during transpassive dissolution of Ni-based alloys[J]. Corrosion Sci. 147, 32-40. doi:10.1016/j.corsci.2018.11.005

Hendersona, J. D., Ebrahimia, N., Dehnavia, V., Guo, M., Shoesmith, D. W., and Noël, J. J. (2018). The role of internal cathodic support during the crevice corrosion of Ni-Cr-Mo alloys[J]. Electrochimica Acta 283, 1600-1608. doi:10.1016/j.electacta.2018.07.048

Javidi, M., and Bekhrad, S. (2018). Failure analysis of a wet gas pipeline due to localised CO2 corrosion[J]. Eng. Fail. Anal. 89, 46-56. doi:10.1016/ j.engfailanal.2018.03.006

JianqiaoYang, S. W., Li, Y., and Xu, D. (2020). Under-deposit corrosion of Ni-based alloy 825 and $\mathrm{Fe}-\mathrm{Ni}$ based alloy 800 in supercritical water oxidation environment[J]. Corrosion Sci. 167, 108493. doi:10.1016/j.corsci.2020.108493

Kirchheim, R., Heine, B., Fischmeister, H., Hofmann, S., Knote, H., and Stolz, U. (1989). The passivity of iron-chromium alloys[J]. Corrosion Sci. 29 (7), 899-917. doi:10.1016/0010-938X(89)90060-7

Laszczyńska, A., Tylus, W., Winiarski, J., and Szczygieł, I. (2017). Evolution of corrosion resistance and passive film properties of Ni-Mo Alloy coatings during exposure to $0.5 \mathrm{M} \mathrm{NaCl}$ solution[J]. Surf. Coat. Tech. 317, 26-37. doi:10.1016/ j.surfcoat.2017.03.043

Li, J., Sun, C., Roostaei, M., Mahmoudi, M., Fattahpour, V., Zeng, H., et al. (2020). Characterization and corrosion behavior of electroless Ni-Mo-P/Ni-P composite coating in $\mathrm{CO}_{2} / \mathrm{H}_{2} \mathrm{~S} / \mathrm{Cl}^{-}$brine: Effects of Mo addition and heat treatment[J]. Surf. Coat. Tech. 403, 126416. doi:10.1016/ j.surfcoat.2020.126416

Li, L., Wang, J., Xiao, J., Yan, J., Fan, H., sun, L., et al. (2021). Time-dependent corrosion behavior of electroless Ni-P coating in $\mathrm{H}_{2} \mathrm{~S} / \mathrm{Cl}^{-}$environment[J]. Int. J. Hydrogen Energ. 46 (21), 11849-11864. doi:10.1016/j.ijhydene.2021.01.053

\section{FUNDING}

This work was supported by the Fundamental Research Funds for the Central Universities (FRF-TP-20-098A1) and National Natural Science Foundation of China (No. 51871027).

Li, X., Henderson, J. D., Filice, F. P., Zagidulin, D., Biesinger, M. C., Sun, F., et al (2020). The contribution of $\mathrm{Cr}$ and $\mathrm{Mo}$ to the passivation of $\mathrm{Ni22} \mathrm{Cr}$ and Ni22Cr10Mo alloys in sulfuric acid[J]. Corrosion Sci. 176, 109015. doi:10.1016/ j.corsci.2020.109015

Monnot, M., Nogueira, R. P., Roche, V., Berthomé, G., Chauveau, E., Estevezb, R., et al. (2017). Sulfide stress corrosion study of a super martensitic stainless steel in $\mathrm{H}_{2} \mathrm{~S}$ sour environments: Metallic sulfides formation and hydrogen embrittlement [J]. Appl. Surf. Sci. 394, 132-141. doi:10.1016/j.apsusc.2016.10.072

Natishan, P. M., Jones-Meehan, J., Loeb, G. I., Little, B. J., Ray, R., and Beard, M. (1999). Corrosion Behavior of Some Transition Metals and 4340 Steel Metals Exposed to Sulfate-Reducing Bacteria[J]. Corrosion 55, 1062-1068. doi:10.5006/1.3283943

Nimmervoll, M., Schmid, A., Mori, G., Honig, S., and Haubner, R. (2021). Surface sulphide formation on high-temperature corrosion resistant alloys in a $\mathrm{H}_{2} \mathrm{~S}-\mathrm{HCl}-\mathrm{CO}_{2}$ mixed atmosphere[J]. Corrosion Sci. 181, 109241. doi:10.1016/j.corsci.2021.109241

Sun, C., Zeng, H., and Luo, J. (2019). Unraveling the effects of $\mathrm{CO}_{2}$ and $\mathrm{H}_{2} \mathrm{~S}$ on the corrosion behavior of electroless Ni-P coating in $\mathrm{CO}_{2} / \mathrm{H}_{2} \mathrm{~S} / \mathrm{Cl}^{-}$environments at high temperature and high pressure[J]. Corrosion Sci. 148, 317-330. doi:10.1016/j.corsci.2018.12.022

Tomio, A., MasayukiSagara, T. D., HisashiAmaya, N. O., and Kudo, T. (2015). Role of alloyed molybdenum on corrosion resistance of austenitic Ni-Cr-Mo-Fe alloys in $\mathrm{H}_{2} \mathrm{~S}$-Cl-environments[J]. Corrosion Sci. 98, 391-398. doi:10.1016/ j.corsci.2015.05.053

Wang, Z., Feng, Z., and Zhang, L. (2020). Effect of high temperature on the corrosion behavior and passive film composition of $316 \mathrm{~L}$ stainless steel in high H2S-containing environments[J]. Corrosion Sci. 174, 108844. doi:10.1016/ j.corsci.2020.108844

Wang, Z., Zhang, L., Tang, X., and Minxu, L. (2017). The surface characterization and passive behavior of Type $316 \mathrm{~L}$ stainless steel in $\mathrm{H}_{2} \mathrm{~S}$-containing conditions[J]. Appl. Surf. Sci. 423, 457-464. doi:10.1016/j.apsusc.2018.07.12210.1016/j.apsusc.2017.06.214

Wang, Z., Zhang, L., Zhang, Z., and Minxu, L. (2018). Combined effect of pH and $\mathrm{H} 2 \mathrm{~S}$ on the structure of passive film formed on type $316 \mathrm{~L}$ stainless steel[J]. Appl. Surf. Sci. 458, 686-699. doi:10.1016/j.apsusc.2018.07.122

Zhang, X., and Shoesmith, D. W. (2013). Influence of temperature on passive film properties on Ni-Cr-Mo Alloy C-2000[J]. Corrosion Sci. 76, 424-431. doi:10.1016/j.corsci.2013.07.016

Zhao, X. H., Han, Y., Bai, Z. Q., and Wei, B. (2011). The experiment research of corrosion behaviour about Ni-based alloys in simulant solution containing H2S/CO2[J]. Electrochimica Acta 56 (22), 7725-7731. doi:10.1016/ j.electacta.2011.05.116

Conflict of Interest: Authors XF, YY, LC, and LD are employed by the China Petroleum Engineering and Construction Co., Ltd. Beijing Company.

The remaining authors declare that the research was conducted in the absence of any commercial or financial relationships that could be construed as a potential conflict of interest.

Publisher's Note: All claims expressed in this article are solely those of the authors and do not necessarily represent those of their affiliated organizations, or those of the publisher, the editors and the reviewers. Any product that may be evaluated in this article, or claim that may be made by its manufacturer, is not guaranteed or endorsed by the publisher.

Copyright (C) 2021 Feng, Fan, Wang, Yu, Chen, Du and Dong. This is an open-access article distributed under the terms of the Creative Commons Attribution License (CC $B Y)$. The use, distribution or reproduction in other forums is permitted, provided the original author(s) and the copyright owner(s) are credited and that the original publication in this journal is cited, in accordance with accepted academic practice. No use, distribution or reproduction is permitted which does not comply with these terms. 